\title{
Praktijk Praktijk
}

\section{"Snuffie" helpt jonge kinderen met hun diabetes om te gaan}

Esther Hosli*

In Nederland hebben ruim 300 kinderen van drie tot zes jaar diabetes mellitus en dit aantal neemt de laatste jaren snel toe. Diabetes grijpt diep in op het dagelijkse leven van een jong kind en op dat van het gezin. Kinderen met diabetes krijgen te maken met een regime van vaste eettijden, een vastgestelde hoeveelheid voedsel, bloedprikken en insuline spuiten. Vaak begrijpen zij zelf de achterliggende redenen hiervan nog niet. Voor ouders is het vaak onduidelijk wat het kind kan begrijpen en hoe ze dingen het beste uit kunnen leggen. Voorlichtingsmateriaal dat is afgestemd op het ontwikkelingsniveau van het kind kan zowel kinderen als ouders concrete handvatten geven om met de aandoening om te gaan, maar was nog niet beschikbaar. Daarom heeft TNO Kwaliteit van Leven, in opdracht van ZonMw, voorlichtingsmateriaal voor peuters en kleuters met diabetes en hun ouders ontwikkeld.

\section{DOELSTELLINGEN EDUCA- TIEMATERIAAL}

De uiteindelijke doelstelling van het materiaal is kinderen te helpen om een positieve en opbouwende houding ten opzichte van hun aandoening te vormen en daardoor de diabetes goed te integreren in hun leven. De concrete doelstellingen die richtinggevend waren bij de ontwikkeling van het materiaal zijn: het al op jonge leeftijd bespreekbaar maken van leefregels en emotionele consequenties van diabetes; aansluiten bij het ontwikkelingsniveau van het kind door een fo-

${ }^{*}$ TNO Kwaliteit van Leven, Leiden cus op concrete ervaringen en herkenning; het kind een "maatje" geven waarmee het zich kan identificeren; ouders concrete handvatten geven voor de omgang met hun kind; en ouders ondersteunen in de communicatie met hun kind over diabetes.

\section{AANPAK}

Voor de kinderen hebben we gekozen voor het ontwikkelen van een voorleesboek met prenten. In het voorleesboek staan verhalen over het konijn Snuffie, dat diabetes heeft. De verhalen gaan over alledaagse en bijzondere gebeurtenissen, waarin de invloed van diabetes hierop verwerkt is. Om vast te stellen welke thema's in de verhalen aan de orde moesten komen hebben de onderzoeker, enkele zorgverleners en enkele ouders gezamenlijk domeinen geformuleerd die belangrijk zijn in het leven van jonge kinderen met diabetes (bijvoorbeeld "de aandoening / diabetes", "bijzondere dag of gebeurtenis" en "verzet”). Bij elk domein hebben we concrete thema's geformuleerd (bijvoorbeeld "diagnose", "veel snoepen op een bijzondere dag", "niet willen bloedprikken"). In elk verhaal staat een van deze thema's centraal. Belangrijk is dat het verhaal in eerste instantie gaat over gebeurtenissen die Snuffie meemaakt, hij gaat bijvoorbeeld naar het partijtje van een vriendje. De invloed van de diabetes komt in het verhaal "terloops" aan de orde. Bij het voorleesboek hoort een knuffelkonijn. Deze "echte" Snuffie is een "maatje" voor de kinderen, met wie ze hun ervaringen kunnen “delen”.
In eerste instantie zouden we voor de ouders een korte handleiding bij het verhalenboek schrijven. Gaandeweg het project bleek echter dat er zoveel was om over te dragen aan ouders, dat voor hen uiteindelijk een informatieboek bij het verhalenboek werd ontwikkeld. Het informatieboek voor de ouders is opgebouwd rond de verhalen. Elk verhaal heeft een begeleidend hoofdstuk in het informatieboek waarin onderwerpen die in het verhaal aan de orde komen worden uitgewerkt, vanuit verschillende perspectieven: het perspectief van het kind, van de ouders, van het gezin en van de omgeving. Dit gebeurt aan de hand van informatieve tekst, anekdotes, tips en opdrachtjes die ouders samen met hun kind kunnen uitvoeren.

Bij de ontwikkeling van het materiaal zijn ervaringsdeskundigheid, praktijkervaring vanuit de zorgverlening en wetenschappelijke inzichten over het denken van kinderen over ziekte bijeen gebracht. De voorleesverhalen zijn geschreven door een jongvolwassene die zelf op jongere leeftijd diabetes kreeg. Het informatieboek is geschreven door een psycholoog met veel ervaring binnen de diabeteszorg en tevens moeder van een dochter met diabetes en door een psycholoog-onderzoeker met expertise op het terrein van het denken van kinderen over ziekte. Bij het gehele project is een klankbordgroep betrokken geweest, die bestond uit ouders, zorgverleners en vertegenwoordigers van de Diabetesvereniging Nederland (DVN). De leden van de klankbordgroep hebben onder andere alle teksten becommentarieerd. Toen de eerste vijf (van vijftien) verhalen, prenten en informatiehoofdstukken klaar waren zijn deze 'gepretest' bij enkele gezinnen 
die niet eerder bij het project betrokken waren geweest. Voor deze vorm van pretesten is gekozen omdat het op dat moment in het project nog mogelijk was om substantiële veranderingen door te voeren. Dit was overigens niet nodig: uit de pretest bleek dat de gezinnen zich goed konden vinden in de gekozen opzet, en dat ze de verhalen, de prenten en de teksten uit het informatieboek goed bruikbaar en informatief vonden.

\section{M PLEMENTATIE}

Het uiteindelijke voorlichtingsmateriaal bestaat uit een kleurrijk koffertje, met daarin de boeken "Snuffie, het konijn met diabetes" en " 25 uur per dag diabetes" en een knuffelkonijn. Het is verkrijgbaar bij de DVN en bij een bedrijf dat onder andere diabeteszelfzorgproducten levert aan ziekenhuizen en particulieren. Voor deze vorm van verspreiding is gekozen omdat zowel de patiëntenvereniging als het bedrijf een infrastructuur hebben waarmee ze, ook op langere ter- mijn, een groot deel van de jonge kinderen met diabetes kunnen bereiken.

Al tijdens het project hebben we bekendheid aan het project gegeven, onder andere door een informatieblad dat we konden verspreiden op beurzen, congressen en bijeenkomsten van de patiëntenvereniging. Toen het materiaal uitkwam is er veel publiciteit aan gegeven, via verschillende kanalen (onder andere algemene pers, gerichte media, vakbladen, relevante internetsites, lezingen op relevante bijeenkomsten).

Uit een gebruikersonderzoek, dat we een jaar na het uitkomen van het materiaal uitgevoerd hebben, bleek dat het materiaal in het eerste jaar na verschijnen breed verspreid is en door gezinnen en zorgverleners goed ontvangen is. In de doelgroep, kinderen van drie tot en met zeven jaar, is het voorleesboek door $85 \%$ van de respondenten gebruikt en heeft $75 \%$ van de ouders het informatieboek gedeeltelijk of helemaal gelezen. De resultaten van het gebruikersonderzoek laten ook zien dat we erin geslaagd zijn de doelstellingen van het materiaal voor een belangrijk deel te verwezenlijken. De kinderen zelf bijvoorbeeld waar- deren de herkenning en identificatie (Snuffie heeft ook diabetes, Snuffie moet dezelfde dingen doen als ik) en het krijgen van een "maatje" het meest. Het materiaal draagt bij aan het bespreekbaar maken van de diabetes en het informatieboek geeft ouders daadwerkelijk concrete handvatten in de omgang met de diabetes.

Het "Snuffie" concept is daarmee succesvol gebleken voor peuters en kleuters met diabetes en hun ouders. Het leent zich echter ook voor toepassing bij andere doelgroepen, bijvoorbeeld kinderen met andere chronische aandoeningen. En een leeftijdsgerichte benadering - meer ontwikkelingspsychologie in voorlichting en educatie - zal ongetwijfeld ook voor andere leeftijdsgroepen vruchtbaar zijn.

\section{CORRESPONDENTIEADRES}

Esther Hosli, TNO Kwaliteit van Leven, Preventie en Zorg, Postbus 2215, 2301 CE Leiden, tel. 071 5181822, e-mail: esther.hosli@tno.nl 